\title{
Pemberian makanan enteral berformulasi bahan pangan lokal terhadap kadar zat besi dan hemoglobin pada tikus putih (Rattus norvegicus)
}

The feeding of enteral nutrition formulated with local food material toward the level of haemoglobin and iron in white rat (Rattus norvegicus)

Dini Ariani' ${ }^{1}$ Mukhamad Angwar ${ }^{1}$, Yuniar Khasanah ${ }^{1}$, Ratnayani $^{1}$, Titin Nuraeni ${ }^{1}$

\begin{abstract}
Background: Enteral nutrition is nutrition used to fulfill the needs of nutrition entirely and as the suplement for malnutrition patient. In a certain condition of patient, this nutrition is usually given in the form of liquid. Local material foods such as tempe, rice, mung bean, and ganyong have adequate nutrition, therefore they are suitable for being used as main raw materials in the making of enteral nutrition. Objective: To know the influence of feeding enteral nutrition formulated with local food material toward malnutritious white rats (Rattus norvegicus) of which the parameters are iron ( $\mathrm{Fe}$ ), haemoglobin ( $\mathrm{Hb}$ ) level and weight. Method: This research used Completely Random Design (CRD). Twenty seven of malnutritious male white rats were devided into 3 groups of treatment with 9 repetition for each groups of the treatment. Group A was given enteral nutrition diet of formula A (tempe, rice, and mung bean as the main raw material), group B was given enteral nutrition diet of formula B (tempe, rice, mung bean, and ganyong as the main raw material), and group C (as the positive control) was given commercial enteral nutrition. The daily giving of enteral nutrition is $20 \mathrm{~g} /$ day during 30 days. The analysis of $\mathrm{Fe}$ and $\mathrm{Hb}$ level and the measurement of weight firstly was done before the treatment is given. The next measurement was conducted in $15^{\text {th }}$ day and $31^{\text {st }}$ day. Statistical analysis used ANAVA test dan DMRT of significance 5\%. Results: The result showed that the treatment of the enteral nutrition feeding of formula B was more optimal than formula $A$ in terms of the way to increase the level of $\mathrm{Hb}$ and $\mathrm{Fe}$. Those two components will give positive effect toward the increasing of the weight of malnutritious white rats (Rattus norvegicus). Conclusion: The enteral nutrition of formula B is more proper to be developed as the main material of making enteral food in order to treat the malnutrition.
\end{abstract}

KEY WORDS: enteral nutrition, malnutrition, local food material, haemoglobin, iron

\begin{abstract}
ABSTRAK
Latar belakang: Makanan enteral merupakan makanan yang digunakan untuk memenuhi kebutuhan gizi secara keseluruhan maupun sebagai suplemen pada penderita yang mengalami malnutrisi. Pada kondisi pasien tertentu, makanan ini biasanya diberikan dalam bentuk cair. Bahan pangan lokal seperti tempe, beras, kacang hijau, dan ganyong memiliki kandungan gizi yang cukup tinggi sehingga layak digunakan sebagai bahan utama dalam pembuatan makanan enteral. Tujuan: Mengetahui pengaruh pemberian makanan enteral berformulasi bahan pangan lokal terhadap tikus putih (Rattus norvegicus) malnutrisi dengan parameter berat badan (BB), hemoglobin (Hb), dan zat besi (Fe). Metode: Penelitian ini menggunakan rancangan acak lengkap (RAL). Sebanyak 27 tikus putih jantan malnutrisi dibagi dalam 3 kelompok perlakuan dengan 9 ulangan pada masing-masing kelompok perlakuan. Kelompok A diberi diit makanan enteral formula A (tempe, beras, dan kacang hijau sebagai bahan utama), kelompok B diberi diit makanan enteral formula B (tempe, beras, kacang hijau, dan ganyong sebagai bahan utama), dan kelompok C sebagai kontrol positif diberi diit makanan enteral komersial. Makanan enteral tersebut diberikan setiap hari sebanyak $20 \mathrm{~g} /$ hari selama 30 hari dan dilakukan penimbangan sisa pakan setiap harinya. Pengukuran BB, kadar Hb, dan Fe dilakukan pada hari ke-0, ke-15, dan ke-31. Analisis data dengan menggunakan uji ANAVA dan uji DMRT pada taraf 5\%. Hasil: Pemberian perlakuan makanan enteral formula B lebih optimal dalam meningkatkan kadar $\mathrm{Hb}$ dan Fe yang akan memberikan pengaruh positif terhadap peningkatan BB pada tikus putih (Rattus norvegicus) malnutrisi jika dibandingkan dengan penggunaan makanan enteral formula A. Simpulan: Formula B lebih layak untuk dikembangkan sebagai bahan penyusun utama dalam pembuatan makanan enteral untuk mengatasi malnutrisi.
\end{abstract}

KATA KUNCI: makanan enteral, malnutrisi, bahan pangan lokal, haemoglobin, zat besi

\section{PENDAHULUAN}

Dewasa ini perhatian terhadap terjadinya malnutrisi pada penderita yang sedang dirawat di rumah sakit telah meningkat. Kejadian malnutrisi pada pasien yang dirawat
Korespondensi: Unit Pelaksana Teknis Balai Pengembangan Proses dan Teknologi Kimia Lembaga Ilmu Pengetahuan Indonesia (LIPI) Gading, Playen, Gunungkidul, Telp/Fax: 0274-392570/391168,e-mail: dini003@lipi.go.id; dini_upt@yahoo.co.id 
di beberapa rumah sakit di Jakarta sebesar 20-60\% (1). Malnutrisi merupakan semua kelainan gizi yang dapat disebabkan oleh ketidakseimbangan atau ketidakcukupan asupan makanan ke dalam tubuh atau adanya gangguan metabolisme makanan di dalam tubuh (2). Risiko terjadinya malnutrisi dapat mengakibatkan penurunan berat badan yang biasanya akan diikuti dengan rendahnya kadar zat besi $(\mathrm{Fe})$, hemoglobin (Hb), dan albumin (Alb) sehingga status gizi menurun (3). Penurunan status gizi ini terjadi karena tubuh mengalami defisiensi zat-zat gizi makro seperti protein dan defisiensi zat-zat gizi mikro seperti Fe.

Upaya untuk mengatasi malnutrisi adalah dengan pemberian asupan makanan yang adekuat, salah satunya adalah dengan pemberian makanan enteral. Makanan enteral merupakan makanan yang diberikan untuk memenuhi kebutuhan gizi secara keseluruhan maupun sebagai suplemen pada pasien yang diindikasikan akan atau mengalami malnutrisi (4). Makanan enteral yang beredar saat ini umumnya diimpor sehingga harganya mahal dan tidak dapat dijangkau oleh masyarakat Indonesia golongan ekonomi bawah. Guna mengatasi masalah tersebut maka dikembangkan makanan enteral dengan memanfaatkan bahan pangan lokal Indonesia yaitu dari tempe, kacang hijau, beras, dan ganyong sebagai bahan utamanya.

Tempe dipilih sebagai salah satu bahan utama berdasarkan keunggulan yang dimiliki. Tempe dapat dijadikan sumber protein yang aman dan murah dengan nilai cerna (digestibility) yang tinggi (5). Kacang hijau memiliki kelebihan dibandingkan kacang-kacangan lainnya, yaitu adanya tripsin inhibitor yang sangat rendah, paling mudah dicerna, dan paling kecil memberi pengaruh flatulensi (gas dalam lambung). Kacang hijau juga mempunyai nilai gizi yang tinggi serta dapat digunakan sebagai sumber vitamin dan mineral (6). Sementara itu, penggunaan beras karena merupakan salah satu bahan makanan pokok di Indonesia dan sumber energi bagi manusia. Pada penelitian ini, ganyong juga dipilih menjadi sumber bahan pangan lokal untuk makanan enteral karena selain mengandung karbohidrat yang cukup tinggi, juga mempunyai kandungan Fe yang tinggi yaitu sebesar 20-22 mg/100 g (7).

Salah satu cara untuk mengetahui status gizi adalah dengan melakukan pengukuran berat badan dan kadar biokimia darah ( $\mathrm{Hb}$ dan $\mathrm{Fe}$ ). Pengukuran berat badan digunakan karena sangat dipengaruhi oleh perubahan-perubahan yang terjadi pada keadaan gizi sehingga pada umumnya berat badan akan turun dengan menurunnya asupan makanan dan asupan gizi (8). $\mathrm{Hb}$ merupakan komponen utama eritrosit dan merupakan suatu protein yang banyak mengandung besi serta berperan penting dalam membawa oksigen dari paruparu ke seluruh jaringan tubuh (9). Pemeriksaan kadar $\mathrm{Hb}$ sering dilakukan sebagai salah satu parameter untuk mengindikasi adanya anemia dan malnutrisi yang dapat mengakibatkan penurunan status gizi. Sementara itu, $\mathrm{Fe}$ merupakan unsur mikronutrien yang diperlukan dalam hemopoesis (pembentukan darah) yaitu dalam sintesis $\mathrm{Hb}$ (10). Dengan berkurangnya penyerapan Fe, maka jumlah feritin ( $\mathrm{Fe}$ yang tersimpan dalam tubuh) juga akan berkurang yang akan berdampak pada menurunnya jumlah $\mathrm{Fe}$ yang akan digunakan untuk sintesis $\mathrm{Hb}$ sehingga dapat menimbulkan anemia (11).

Oleh karena itu, tujuan penelitian ini adalah untuk mengetahui pengaruh pemberian makanan enteral berformulasi bahan pangan lokal terhadap tikus putih (Rattus norvegicus) malnutrisi dengan parameter kadar $\mathrm{Hb}$, kadar Fe, dan berat badan, serta untuk mengetahui formula makanan enteral yang memberikan hasil paling optimal dalam meningkatkan parameter tersebut.

\section{BAHAN DAN METODE}

Bahan utama yang digunakan dalam penelitian ini adalah hewan uji tikus putih (Rattus norvegicus) jantan strain Wistar berumur 2 bulan yang diperoleh dari Laboratorium Penelitian dan Pengujian Terpadu Layanan Penelitian Pra-Klinik dan Pengembangan Hewan Percobaan (LPPT-LP3HP) Universitas Gadjah Mada (UGM) Yogyakarta. Makanan enteral yang digunakan (Tabel 1), yaitu formula A dan formula B merupakan hasil formulasi di Unit Pelaksana Teknis Balai Pengembangan Proses dan Teknologi Kimia Lembaga Ilmu Pengetahuan Indonesia (UPT BPPTK LIPI) Yogyakarta (12), dan sebagai kontrol digunakan produk komersial (formula C). Bahan lain yang digunakan adalah pakan gogek, Kit dari DIASYS (untuk pemeriksaaan kadar $\mathrm{Hb}$ ), $\mathrm{HCl}$, dan $\mathrm{HNO}_{3}$ pekat. Peralatan utama yang digunakan antara 
Tabel 1. Formulasi makanan enteral yang digunakan sebagai perlakuan (jumlah/100 g bahan)

\begin{tabular}{lclcl}
\hline \multicolumn{1}{c}{ Formula A } & & \multicolumn{2}{c}{ Formula B } & Formula C \\
\hline Nama bahan & Jumlah & Nama bahan & Jumlah & Nama bahan \\
\hline Tepung beras & $35 \%$ & Tepung beras & $20 \%$ & Kaseinat \\
Tepung tempe & $20 \%$ & Tepung tempe & $20 \%$ & Lesitin kedelai \\
Tepung kacang hijau & $15 \%$ & Tepung kacang hijau & $15 \%$ & Minyak nabati \\
Gula & - & Gula & - & Maltodekstrin \\
Margarin & - & Margarin & - & Sukrosa \\
& & Tepung ganyong & $15 \%$ & Oligosakarida \\
& & & & Vitamin \\
& & & & Mineral \\
\hline
\end{tabular}

Keterangan: Jumlah dari gula dan margarin pada formulasi A dan B tiap $100 \mathrm{~g}$ bahan, besarnya sama

lain spektrofotometer $\mathrm{HACH} \mathrm{DR} / 2000$, flame atomic absorption spectrofotometer (F-AAS) Perkin Elmer model 3110, peralatan gelas, dan mikrohematokrit. Penelitian ini dilaksanakan pada bulan Februari sampai April 2009 dan dilakukan sepenuhnya oleh tim peneliti UPT BPPTK LIPI dibantu teknisi atau laboran di Laboratorium Pusat Studi Pangan dan Gizi (PSPG) UGM Yogyakarta sekaligus sebagai tempat untuk pemeliharaan hewan uji, perlakuan, serta tempat untuk analisis kadar $\mathrm{Hb}$ sedangkan Laboratorium Kimia Analitik Fakultas Matematika dan Ilmu Pengetahuan Alam (FMIPA) UGM digunakan sebagai tempat untuk analisis kadar Fe.

Kandungan gizi formula makanan enteral yang digunakan dalam penelitian ini secara lengkap tercantum pada Tabel 2. Rancangan percobaan berupa rancangan acak lengkap (RAL) menggunakan 3 kelompok perlakuan dengan 9 ulangan pada masing-masing kelompok perlakuan. Kondisi malnutrisi dibuat dengan cara pemberian pakan gogek sebanyak $20 \mathrm{~g}$ /hari selama 14 hari secara ad libittum. Pakan gogek merupakan pakan yang terbuat dari singkong yang disawut dan dimasak dengan cara dikukus kemudian dikeringkan (seperti gaplek tetapi ukurannya lebih kecil). Setelah pemberian pakan gogek selama 14 hari, hewan coba diperiksa berat badan, kadar $\mathrm{Fe}$, dan $\mathrm{Hb}$ (hari ke-0). Parameter tikus malnutrisi adalah berat badan kurang dari 150 g, kadar Hb kurang dari 10 $\mathrm{g} / \mathrm{dL}$, dan kadar Fe total dalam darah kurang dari 350 $\mu \mathrm{g} / \mathrm{ml}$ (13).

Makanan enteral dalam bentuk tepung dibuat pellet. Tikus putih diberi perlakuan pakan pellet yang dibuat dari makanan enteral formula A, B, dan C sebanyak 20 g/tikus/hari. Pakan dan minum tikus diberikan secara
Tabel 2. Nilai nutrisi makanan enteral yang digunakan sebagai perlakuan (kadar/100 g bahan)

\begin{tabular}{lccc}
\hline \multicolumn{1}{c}{ Komposisi } & $\begin{array}{c}\text { Formula } \\
\text { A }\end{array}$ & $\begin{array}{c}\text { Formula } \\
\text { B }\end{array}$ & $\begin{array}{c}\text { Formula } \\
\text { C }\end{array}$ \\
\hline Kadar air (g) & 3,66 & 3,67 & 2,89 \\
Kadar abu (g) & 1,26 & 1,56 & 2,04 \\
Lemak (g) & 9,45 & 9,49 & 10,35 \\
Protein (g) & 16,56 & 16,32 & 11,9 \\
Serat kasar (g) & 7,92 & 6,34 & - \\
Karbohidrat (g) & 61,78 & 62,65 & 71,4 \\
Kalori (Kal) & 398 & 401 & 425 \\
Na (mg) & 0,10 & 0,11 & 221 \\
K (mg) & 0,11 & 0,16 & 306 \\
Ca (mg) & 0,23 & 0,24 & 226,1 \\
Mg (mg) & 0,03 & 0,03 & 107,1 \\
Fe (mg) & 3,11 & 3,48 & 2,89 \\
P (mg) & 0,13 & 0,14 & 25,86 \\
Cl (mg) & 0,15 & 0,15 & 10,34 \\
Glukosa (mg) & 17,77 & 17,21 & - \\
Osmolaritas (mOsm/L) & - & - & 300 \\
\hline
\end{tabular}

Sumber: (11)

ad libittum. Perlakuan diberikan setiap pagi hari sekitar pukul 07.00-08.00 WIB selama 30 hari. Pada hari ke15 dan ke-31 setelah perlakuan, kembali dilakukan pengambilan darah untuk pengukuran kadar $\mathrm{Fe}$ dan $\mathrm{Hb}$, serta dilakukan penimbangan berat badan tikus.

Kadar zat besi total dalam darah diukur dengan F-AAS. Sebanyak $1 \mathrm{ml}$ sampel darah dimasukkan ke dalam cawan porselen, dipanaskan dengan menggunakan oven pada suhu $110^{\circ} \mathrm{C}$ selama $5 \mathrm{jam}$. Kemudian dilanjutkan dengan memanaskan sampel tersebut ke dalam mufel furnase dengan suhu $500-600^{\circ} \mathrm{C}$ selama 6 jam. Setelah terbentuk abu, sampel dipindahkan ke dalam gelas labu atau labu ukur $100 \mathrm{ml}$, ditambahkan 50 
$\mathrm{ml}$ aquarigia (merupakan campuran dari $\mathrm{HCl}: \mathrm{HNO}_{3}=$ $1: 3$ ) dan dipanaskan di atas hot plate dengan suhu $100^{\circ}$ $\mathrm{C}$ selama semalam. Setelah kering, sampel dipindahkan kembali ke dalam gelas labu yang baru, ditambahkan 1-2 $\mathrm{ml} \mathrm{HNO}_{3}$ pekat kemudian dipanaskan kembali hingga jernih. Sampel yang telah jernih dipindahkan ke dalam botol film. Setelah itu, dilakukan pengenceran dengan menambahkan $10 \mathrm{ml}$ aquades. Sampel kemudian dianalisis dengan menggunakan alat F-AAS pada panjang gelombang 248,3 nm dan hasilnya dibandingkan dengan hasil kurva pada larutan standar besi.

Pengukuran kadar Hb dilakukan dengan menggunakan kit dari DIASYS. Cara pengukurannya adalah sebanyak $20 \mu \mathrm{l}$ darah dimasukkan ke dalam tabung reaksi, kemudian ditambahkan reagen (yang terdiri dari campuran potassium cyanida, potassium hexacyanoferrate, buffer fosfat, dan detergen) sebanyak $5000 \mu 1$ dan dicampur dengan menggunakan vorteks hingga homogen. Detergen digunakan untuk mempercepat dan menyempurnakan reaksi antara sampel dan reagen. Setelah itu, diinkubasi selama 3 menit lalu dibaca absorbansinya pada spektrofotometer dengan panjang gelombang $540 \mathrm{~nm}$. Sebagai blanko digunakan larutan reagen sebanyak $5000 \mu 1$. Kadar $\mathrm{Hb}$ dapat dihitung dengan rumus : absorbansi $\times 36,8 \mathrm{~g} / \mathrm{dL}$.

Pengukuran berat badan dilakukan dengan cara kandang tikus ditimbang terlebih dahulu, setelah itu tikus dimasukkan ke dalam kandang dan dilakukan penimbangan kembali terhadap kandang dan tikus. Berat badan tikus diperoleh dengan menghitung selisih antara berat tikus dan kandang dikurangi berat kandang. Penimbangan dilakukan mengunakan analitik Sartorius. Data yang diperoleh dianalisis secara statistik dengan menggunakan analysis of variance (ANAVA) kemudian dilakukan duncan multiple range test (DMRT) pada taraf $5 \%$ apabila menunjukkan hasil yang bermakna untuk mengetahui letak perbedaan antar perlakuan.

\section{HASIL}

Hasil pengukuran kadar Fe dan $\mathrm{Hb}$ menunjukkan bahwa kadar $\mathrm{Fe}$ dan $\mathrm{Hb}$ tikus putih (Rattus norvegicus) malnutrisi mengalami peningkatan setelah diberi perlakuan formula makanan enteral. Nilai rerata peningkatan kadar Fe tertinggi terdapat pada kelompok perlakuan A (formula A) yaitu sebesar $417,99 \mu \mathrm{g} / \mathrm{ml}$. Pada kelompok perlakuan B (formula B) peningkatan kadar Fe sebesar 399,56 $\mu \mathrm{g} / \mathrm{ml}$ sedangkan pada kelompok perlakuan $\mathrm{C}$ (Formula C) peningkatan kadar Fe hanya sebesar 275,15 $\mu \mathrm{g} / \mathrm{ml}$ (Gambar 1).

Nilai rerata peningkatan kadar $\mathrm{Hb}$ tertinggi terdapat pada kelompok perlakuan B (formula B) yaitu sebesar 5,33 g/dl, diikuti kelompok perlakuan C (formula C) 4,91 g/dl, dan kelompok perlakuan A (formula A) 4,03 $\mathrm{g} / \mathrm{dl}$ (Gambar 2). Berat badan pada umumnya akan turun dengan menurunnya asupan makanan dan asupan gizi (8). Sebaliknya, pada saat kondisi asupan makanan dan gizi tercukupi, berat badan akan mengalami peningkatan hingga mencapai berat badan normal. Berdasarkan hasil pengukuran berat badan, menunjukkan bahwa berat badan tikus putih (R.norvegicus) malnutrisi meningkat dengan pemberian formula makanan enteral (Gambar 3).

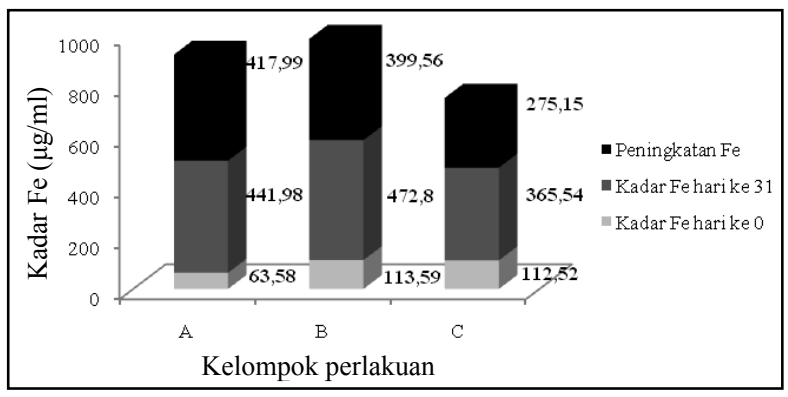

Gambar 1. Histogram rerata peningkatan kadar Fe pada tikus putih (Rattus norvegicus) setelah perlakuan pemberian makanan enteral dengan formula yang berbeda selama 30 hari

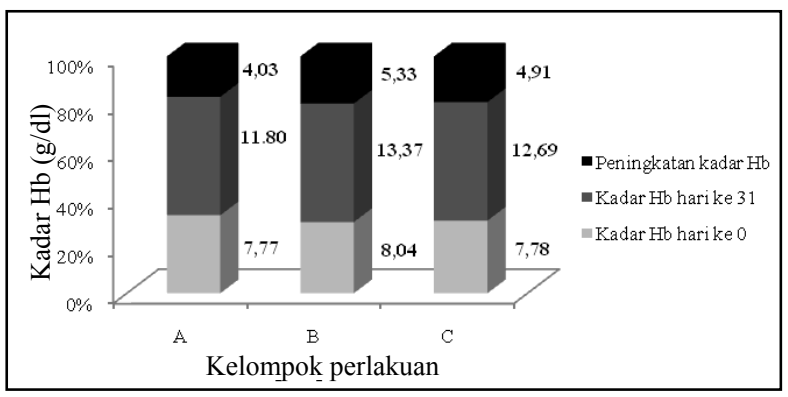

Gambar 2. Histogram rerata peningkatan kadar $\mathbf{H b}$ pada tikus putih (Rattus norvegicus) setelah perlakuan pemberian makanan enteral dengan formula yang berbeda selama 30 hari 


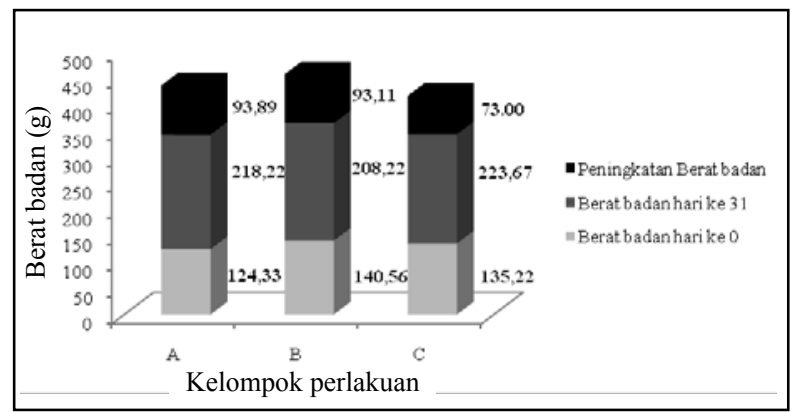

Gambar 3. Histogram rerata peningkatan berat badan pada tikus putih (Rattus norvegicus) setelah perlakuan pemberian makanan enteral dengan formula yang berbeda selama 30 hari

\section{BAHASAN}

\section{Kadar zat besi (Fe)}

Hasil analisis statistik menunjukkan kadar Fe tidak berbeda bermakna antara kelompok perlakuan A dan B sedangkan jika dibandingkan dengan kelompok perlakuan $\mathrm{C}$ menunjukkan hasil yang berbeda bermakna. Kondisi tersebut bisa terjadi karena kelompok perlakuan A dan B mendapat asupan makanan enteral yang berbahan pangan lokal terdiri dari campuran tepung tempe, tepung beras, dan tepung kacang hijau sebagai bahan utama dengan kandungan gizi yang cukup tinggi. Bahkan, formula $\mathrm{B}$ masih diperkaya dengan komponen tepung ganyong sedangkan kelompok $\mathrm{C}$ mendapatkan makanan enteral komersial yang tidak berbahan baku pangan lokal.

Tempe dapat dijadikan sumber protein yang aman dan murah dengan nilai cerna (digestibility) yang tinggi (4). Kacang hijau juga mempunyai nilai gizi yang tinggi serta dapat digunakan sebagai sumber protein, vitamin, dan mineral. Sebagai sumber protein nabati, kandungan protein kacang hijau sekitar 19,04-25,37\% (5). Adapun beras merupakan sumber energi bagi manusia yang mengandung zat-zat gizi yang mudah dicerna dan mempunyai nilai gizi tinggi (14). Tingginya nilai gizi yang terkandung dalam bahan-bahan pangan lokal tersebut berperan dalam menyumbang kandungan zat Fe pada formula A dan B. Hal tersebut tampak dari kandungan Fe pada formula A dan B yang lebih tinggi daripada formula $\mathrm{C}$. Berdasarkan hasil analisis bahan pakan yang diberikan, formula $\mathrm{C}$ mengandung $\mathrm{Fe}$ sebesar 2,89 mg sedangkan formula pakan A dan B secara berturut-turut mengandung Fe sebesar 3,11 mg dan 3,48 mg sehingga berpengaruh pada peningkatan kadar Fe kelompok perlakuan A dan B.

Zat besi merupakan unsur mikronutrien yang penting bagi manusia. Zat besi terutama diperlukan dalam sintesis Hb (10). Pemeriksaan kadar Fe total dalam darah dapat digunakan sebagai indikator progres terjadinya malnutrisi. Hal ini karena Fe merupakan unsur mikronutrien yang berperan penting untuk metabolisme di dalam tubuh. Adanya penurunan kandungan Fe dalam tubuh dapat mengganggu proses metabolisme tersebut sehingga dapat menyebabkan malnutrisi. Zat besi dalam tubuh terdiri dari dua bagian yaitu cadangan dan fungsional. Zat besi cadangan tidak mempunyai fungsi fisiologi selain sebagai buffer, yaitu menyediakan Fe jika dibutuhkan untuk fungsi fisiologi. Zat besi yang bersifat fungsional berbentuk $\mathrm{Hb}$ dan mioglobin. Apabila tubuh kekurangan asupan Fe, maka tubuh akan mengaktifkan Fe cadangan (14).

Absorpsi Fe tidak dipengaruhi oleh banyak sedikitnya makanan yang masuk ke dalam lambung. Faktor yang kemungkinan berpengaruh adalah kadar feritin, seperti yang dibuktikan pada penelitian di Amerika Serikat yang menyatakan bahwa absopsi Fe dipengaruhi oleh status Fe dalam tubuh. Absorpsi Fe akan meningkat pada tubuh dengan cadangan Fe yang rendah (15). Penelitian sebelumnya (16) menyatakan bahwa pada keadaan defisiensi Fe, kemampuan sel-sel mukosa usus dalam mengabsorpsi Fe meningkat 10\% sampai 30\% sehingga jumlah Fe yang masuk ke dalam darah cukup untuk meningkatkan kadar Fe dalam serum. Tubuh yang kekurangan Fe akan mengatur agar kebutuhan Fe untuk pembentukan sel-sel darah merah tetap dapat terpenuhi. Oleh karena itu, sumsum tulang bekerja lebih aktif serta semua kegiatan pencernaan dan absorpsi berlangsung lebih efisien. Dengan demikian, akan lebih banyak Fe yang diserap oleh tubuh.

\section{Kadar hemoglobin (Hb)}

Hemoglobin merupakan komponen utama eritrosit dan merupakan suatu protein yang banyak mengandung Fe dan berperan penting dalam membawa oksigen dari paru-paru ke seluruh jaringan tubuh (9). Sintesis $\mathrm{Hb}$ selain dipengaruhi oleh ketersediaan Fe juga 
dipengaruhi oleh kecukupan protein. Adanya defisiensi $\mathrm{Fe}$ maupun protein dalam asupan makanan sehari-hari dapat menyebabkan terjadinya gangguan sintesis $\mathrm{Hb}$. Asam amino yang berperan dalam proses pembentukan $\mathrm{Hb}$ adalah asam amino glisin dan suksinil-koA untuk menjadikan protoporfirin dan akhirnya menjadi heme setelah berinteraksi dengan $\mathrm{Fe}$ dengan bantuan enzim ferrocelatase. Sementara itu, untuk sintesis globin diperlukan asam amino, biotin, asam folat, vitamin B6, dan vitamin B12 (11). Vitamin B12 berperan dalam menjaga agar sel-sel berfungsi normal, terutama sel-sel dalam sumsum tulang dan saluran pencernaan. Dalam sumsum tulang, koenzim vitamin B12 sangat diperlukan untuk sintesis DNA. Bila DNA tidak diproduksi, eritroblas tidak membelah diri tetapi membesar menjadi megaloblas (17). Hal ini akan mengakibatkan terjadinya anemia karena daya angkut $\mathrm{Hb}$ menjadi sangat terbatas.

Hasil pengukuran kadar $\mathrm{Hb}$ menunjukkan bahwa kadar $\mathrm{Hb}$ tikus putih ( $R$. norvegicus) malnutrisi meningkat setelah pemberian perlakuan formula makanan enteral. Hasil analisis $\mathrm{Hb}$ menunjukkan bahwa peningkatan kadar $\mathrm{Hb}$ tertinggi terdapat pada perlakuan B (formula B) sebesar $5,33 \mathrm{mg} / \mathrm{dl}$ diikuti perlakuan C (formula C) sebesar 4,91 mg/dl, kemudian perlakuan A (formula A) sebesar 4,03 mg/dl. Analisis ANAVA menunjukkan bahwa perbedaan formula makanan enteral yang diberikan berpengaruh bermakna terhadap peningkatan kadar $\mathrm{Hb}$ tikus putih malnutrisi $(\mathrm{p}<0,05)$. Hasil uji DMRT juga menunjukkan perbedaan bermakna pada semua kelompok perlakuan. Kadar $\mathrm{Hb}$ pada kelompok perlakuan A lebih rendah jika dibandingkan dengan kelompok perlakuan B. Hal tersebut disebabkan formula makanan enteral $\mathrm{B}$ diperkaya dengan penambahan tepung ganyong. Ganyong (Canna edulis L.) merupakan salah satu bahan pangan lokal yang memiliki kandungan Fe yang cukup tinggi yaitu sebesar $20-22 \mathrm{mg} / 100 \mathrm{~g}$. Ganyong dengan kandungan Fe yang tinggi ini merupakan salah satu bahan pangan fungsional yang mempunyai potensi untuk dapat meningkatkan kadar $\mathrm{Hb}$ dalam darah pada penderita anemia (6). Adanya penambahan ganyong pada makanan enteral formula B terbukti dapat meningkatkan kandungan Fe dalam formula makanan enteral tersebut jika dibandingkan dengan makanan enteral formula A yang tanpa penambahan ganyong.

\section{Berat badan}

Pertumbuhan berat badan dinyatakan dengan pengukuran berat badan tiap hari atau tiap minggu yang ditentukan oleh banyaknya jumlah makanan yang masuk ke dalam tubuhnya (18). Hasil pengamatan terhadap perubahan berat badan menunjukkan bahwa peningkatan berat badan paling besar terjadi pada kelompok perlakuan A (formula A) yaitu 93,89 g sedangkan pada kelompok perlakuan B (formula B) sebesar 83,11 $\mathrm{g}$ dan pada kelompok perlakuan $\mathrm{C}$ (formula C) sebesar 71,00 g. Hasil uji ANAVA menunjukkan bahwa perbedaan formula makanan enteral yang diberikan adalah faktor yang berpengaruh bermakna terhadap peningkatan berat badan tikus putih yang mengalami malnutrisi $(\mathrm{p}<0,05)$. Hasil uji DMRT juga menunjukkan perbedaan yang bermakna pada semua kelompok perlakuan. Perbedaan peningkatan nilai rerata berat badan pada tikus putih ( $R$. norvegicus) yang mengalami malnutrisi ini dipengaruhi oleh perbedaan komposisi bahan penyusun makanan enteral yang diberikan. Pakan sebagai faktor yang sangat besar pengaruhnya untuk metabolisme di dalam tubuh, aktivitas produksi, dan kelebihannya akan disimpan dalam tubuh dalam bentuk lemak dan daging. Rata-rata jumlah konsumsi makanan mempunyai pengaruh yang kuat dan nyata terhadap kenaikan berat badan (19).

Jika dilihat dari asupan kalori pada masing-masing formula yang diberikan, formula $\mathrm{C}$ memiliki nilai kalori paling tinggi yaitu 425 kal sedangkan formula $\mathrm{B}$ dan formula A secara berturut-turut memiliki kalori sebesar 401 kal dan 398 kal. Namun demikian, efek terhadap peningkatan berat badan justru berkebalikan dengan nilai kalorinya. Berdasarkan penelitian yang sudah dilakukan sebelumnya menyatakan bahwa kelompok perlakuan A (Formula A) memiliki kadar trigliserida yang paling tinggi jika dibandingkan dengan kelompok perlakuan $\mathrm{B}$ (Formula B) dan perlakuan C (Formula C). Trigliserida merupakan lemak utama di dalam tubuh, dibentuk di hati dari gliserol dan lemak yang berasal dari makanan (20). Hampir seluruh trigliserida terutama yang bersifat jenuh dapat diserap oleh tubuh sehingga konsumsi makanan yang mengandung lemak jenuh tinggi memberikan kontribusi besar dalam meningkatkan kadar trigliserida dalam darah. Fungsi utama trigliserida adalah sebagai zat energi. Semantara itu, lemak disimpan di dalam tubuh dalam bentuk trigliserida. Kandungan karbohidrat dalam 
makanan dapat mempengaruhi kadar trigliserida dalam darah, yang selanjutnya akan berpengaruh terhadap berat badan (1). Trigliserida tinggi seringkali berkaitan dengan kegemukan. Kelebihan trigliserida akan ditimbun dalam jaringan di bawah kulit, sehingga berat badan akan cenderung mengalami peningkatan seiring dengan peningkatan kadar trigliserida di dalam tubuh.

\section{SIMPULAN}

Pemberian makanan enteral berformulasi bahan pangan lokal selama 30 hari mampu meningkatkan berat badan, kadar $\mathrm{Hb}$, dan kadar Fe pada tikus putih $(R$. norvegicus) malnutrisi. Peningkatan paling optimal terjadi pada kelompok perlakuan yang diberi makanan enteral formula B (dengan komposisi tempe, beras, kacang hijau, dan ganyong sebagai bahan utama) sehingga formula B lebih layak untuk dikembangkan sebagai bahan penyusun utama dalam pembuatan makanan enteral.

Hasil penelitian ini diharapkan makanan enteral berbahan pangan lokal formula B (dengan komposisi tempe, beras, kacang hijau, dan ganyong) dapat diujikan dan dimanfaatkan untuk mengatasi kasus malnutrisi yang sering terjadi di rumah sakit. Bentuk makanan yang instan (tinggal diseduh), berbasis pangan lokal dengan kandungan gizi yang tinggi, dan harga yang terjangkau masyarakat dapat dijadikan salah satu alternatif pengganti makanan enteral komersial yang selama ini digunakan di rumah sakit.

\section{UCAPAN TERIMA KASIH}

Penulis mengucapkan terimakasih kepada Lembaga Ilmu Pengetahuan Indonesia (LIPI), khususnya UPT BPPTK LIPI yang telah memberikan dana sehingga penelitian ini dapat terlaksana.

\section{RUJUKAN}

1. Almatsier S. Prinsip dasar ilmu gizi. Jakarta: Gramedia Pustaka Utama; 2001.

2. Dorland. Kamus kedokteran edisi 26. Jakarta: EGC Penerbit Buku Kedokteran; 1996.

3. Hartono A. Asuhan nutrisi rumah sakit. Jakarta: EGC Penerbit Buku Kedokteran; 1997.

4. Madjid A. Nutrisi enteral pada penderita kritis. Cermin Dunia Kedokteran 1987;42:14-8.
5. Karyadi D, Hermana H. Potensi tempe untuk gizi dan kesehatan. Bogor: Pusat Penelitian Gizi; 1995.

6. Saneto, Susanto T. Teknologi pengolahan hasil pertanian. Surabaya: PT. Bina Ilmu; 1994.

7. Numala S. Tanaman ganyong bisa jadi substitusi tepung terigu. [serial online] 2005 [cited 2008 Nov 6]. Available from: URL: http.//www.Pikiranrakyat.com.

8. Rokhe JE. Prioritas pediatri di negara berkembang. Yogyakarta: Yayasan Estetika Medika, Penerbit Bukubuku Ilmiah Kedokteran; 1979.

9. Meliana D. Studi banding beberapa metode pengukuran kadar hemoglobin [Skripsi]. Surakarta: Fakultas Kedokteran-UNS; 2004.

10. Achmad DS. Ilmu gizi untuk mahasiswa dan profesi di Indonesia jilid I. Jakarta: Dian Rakyat; 2000.

11. Susilo J, Hadi H. Hubungan asupan zat besi dan inhibitornya sebagai prediktor kadar hemoglobin ibu hamil di Kabupaten Bantul Provinsi DIY. Berita Kedokteran Masyarakat 2002;18(1):1-8.

12. Angwar M, Ariani D, Khasanah Y, Ratnayani P, Ditahardiyani. Pengembangan formula makanan lewat pipa (MLP) menggunakan bahan pangan lokal. Laporan Teknis Kegiatan Penelitian DIPA; UPT BPPTK LIPI Yogyakarta; 2008.

13. Speicher CE, Smith JW. Pemilihan uji laboratorium yang efektif. Kresno SB, editor. Jakarta: EGC Penerbit Buku Kedokteran; 1994.

14. Nurmiyati I. Hubungan tingkat konsumsi protein dan zat besi dengan kadar hemoglobin pada ibu hamil di Puskesmas Kandangan tahun 2005. Berkala Kedokteran 2006;5(1):62-9.

15. Bovell-Benjamin AC, Viteri FE, Allen LH. Iron absorption from ferrous bisglycinate and ferric triglycinate in whole maize is regulated by iron status. Am J Clin Nutr 2000;71(6):1563-9.

16. Triawanti. Pengaruh pemberian zat besi dan kalsium dengan kombinasi dosis terhadap kadar besi serum. Berkala Kedokteran 2002;2(2):9-16.

17. Winarno FG. Kimia pangan dan gizi. Jakarta: Gramedia Pustaka Utama; 2004.

18. Tillman. Ilmu makanan ternak dasar. Yogyakarta: Fakultas Peternakan UGM; 1994.

19. Rahardjo SS, Ngatijan, Pramono S. Influence of etanol extract of jati belanda leaves (Guazuma ulmifolia Lamk.) on lipase enzym activity of rattus norvegicus serum. Inovasi Online 2005;4(XVII):48-54.

20. Ariani D, Angwar M, Khasanah Y, Ratnayani, Ditahardiyani P. Pengembangan formula makanan lewat pipa (MLP) menggunakan bahan pangan lokal. Rencana Kegiatan Penelitian DIPA; UPT BPPTK LIPI Yogyakarta; 2009. 